\title{
ATSKIRTYS VISUOMENINĖJE APLINKOS SAMPRATOJE
}

\author{
Gintaras Čaikauskas \\ Architektūros katedra, Vilniaus Gedimino technikos universitetas, \\ Pylimo g. 26/Traku g. 1, LT-01132 Vilnius, Lietuva \\ El.paštas gintaras.caikauskas@architekturoslinija.lt
}

Itteikta 20090904

Santrauka. Ivairiais aspektais analizuojamos aplinkos estetinės kategorijos, atskleidžiant prieštaravimus tarp socialinio užsakymo, kūrèjų sumanymų bei rezultatų visuomeninès sampratos, taip pat aiškinamasi, kokios yra atskirties atsiradimo priežastys. Architektūros kūryba pateikiama kaip neatsiejama, dominuojanti meninių disciplinų visumos dalis, atspindinti ne tik žmonijos kultūros, bet ir visos civilizacijos raidos ypatybes, besiformuojanti veikiant bendriems evoliucijos dèsniams. Būdingų prieštaravimų ištakos atskleidžia tarpusavio nesusikalbejimo priežastis. Meninès veiklos pasekmès ir vertinimo klausimai analizuojami remiantis ryškesniais šiuolaikiniais pavyzdžiais.

Reikšminiai žodžiai: atskirtis, aplinkos samprata, prieštaravimų pradai.

\section{Ivadas}

Pasikeitus Lietuvos politinei formacijai vis dažniau ir garsiau kalbama apie šalies ekonominès diferenciacijos didèjimą bei realiai juntamą šio proceso rezultatą - socialinę atskirtị. Tendencingai besiformuojanti visuomenė anksčiau - ideologizuota, dabar - vartotojiškai angažuota, turi savus gyvenimo dèsnius ir specifiką. Žmonių sąmonès brandos genezė bei jų veiklos padarinių - dirbtinio ekonomikos auginimo, perkaitimo, krizių analizè dar kartą îrodo, kad individo egzistencinis pagrindas buvo ir išliks ne tiek objektyvi ekonominé platforma, kiek jo paties sau keliamų subjektyvių reikalavimų, susiformuluotų poreikių, susikurtų įvaizdžių bei komercijos primestų šablonų supratimo, jų patenkinimo siekio ir realizuotų galimybių kriterijai. Tai iš esmès yra kultūrinè sąvoka, moralinè kategorija, individo savęs identifikavimo išraiška, esminių veiksmų principų suformulavimas, gyvenimo prasmès, žmogiškosios laimès ir džiaugsmo, asmeniškas pasitenkinimo suvokimas, vertybių ir prioritetų nusistatymas, pilietinis ir tautinis tapatumas, kosmopolitiškumas, visuomenès priimtų normų pripažinimas arba jų neigimas. Visa tai yra neatsiejama nuo asmenybės ugdymo ir švietimo sistemos efektyvumo, platesnio akiračio formavimo, savarankiško išsilavinimo. Nemažiau svarbus žmogaus pamatinis kultūrinis išprusimas, profesinis pasirengimas, šalies ir pasaulio istorijos išmanymas, adekvatus praeities ir dabarties reiškinių supratimas, jų vertinimas, gebejimas daryti išvadas ir jas pritaikyti kasdienybeje, ateities procesų ir konkrečios savo veiklos mechanizmų modeliavimas.

Antra vertus, žmonijos dvasinès prigimties natūralus absoliuto dominavimas prieš materializmo apraiškas bet kokiomis ekonominėmis sąlygomis daugiau ar mažiau yra kultūros imperatyva. Asmenybės gyvenime neišvengiamai jaučiamas nuolatinis estetikos ilgesys ir siekis, kūrybinio pakilimo bei emocinių išgyvenimų poreikis. Jis visuomet yra skirtingas, kiekvienam žmogui - individualus. Sunkiai mokslo terminais apibrěžiama, gana neprofesionaliai skambanti subjektyvi estetinè kategorija - "grožis“ - iš tikrųjų yra labai galinga materiali jèga, dažnai nugalinti net objektyvius ekonominius apskaičiavimus ar iš anksto apgalvotas logines nuostatas. Grožio kategorija išlieka sunkiausiomis, meno gyvavimui nepalankiomis ekonominemis 
aplinkybėmis, savitomis formomis pasireiškia net karų ar kitų negandų laikotarpiais, diktatūrų epochose, tačiau ypač suklesti demokratinèse visuomenèse, ekonominio pakilimo etapuose. Estetikos formavimas dažnai tampa ir paties ekonominio gyvenimo pagrindu, veiklos tikslu, galingu verslo įrankiu ir pelno garantu. Pridètinès meninès vertès sukūrimas bei išliekamosios vertès atsiradimas paprastai siejasi su bendražmogiškosiomis vertybèmis, kūrèjų sugebejjimu jas vienaip ar kitaip pateikti, koduojant savo individualius išgyvenimus bei originalius sumanymus, interpretuoti būsimojo reiškinio idejas, o sociumui ${ }^{1}$ - pagrindiniam meninių produktų vartotojui - reikia adekvačiai jas priimti, suprasti, atskleisti ir ịvertinti. Menas nèra tiesiogiai su objektyviomis mokslinemis kategorijomis susijusi žmonijos veikla, visuomet buvo ir bus grindžiamas subjektyviu aplinkos suvokimu. Objektyvius gamtos dėsnius galima iššifruoti sąmoningai, moksliniais tyrimais, analize ir stebejjimais, o meninès kategorijos dažniausiai priimamos pasąmonės lygmenyje, jos labai dažnai būna skirtingų individų suprantamos visiškai priešingai, individualiai. Tuomet labai išryškèja asmenybès bendros edukacijos, išprusimo klausimai, akiračio, tolerancijos, išankstinio nusistatymo, teigiamo ar neigiamo nusiteikimo, natūralaus esmès nesupratimo, intelektualaus nepasirengimo ar grynai žmogiškojo nenoro įsigilinti ir suprasti naujus, netradicinius aplinkos reiškinius ir už jų slypinčius galimus pavojus.

\section{Kosmopolitinis konceptualusis prieštaravimų pradas}

$\mathrm{XX}$ a. pradžioje atsiradusi pasaulinè modernizmo banga iš esmès buvo susijusi su pažangesnių technologijų, naujų gamybinių santykių atsiradimu, sutapo su technikos progresu bei civilizacijos pažanga. Feodalizmo epocha užleido vietą industriniam kapitalizmui, leidusiam didesnes finansines lèšas paskleisti daug platesniuose socialiniuose sluoksniuose, o kultūrą padaré lengvai prieinamą plačiosioms masėms. Modernizmas demonstratyviai paneigè klasikinio, ypač realistinio meno tradicijas, sulaužè jo kūrybos formas. „<...> ieškojimų rezultatai būdavo ịvairūs: ir neprotingi triukai, ir pražudytų talentų tragedija, ir mados vaikymasis, ir didžiųjų meistrų tikri atradimai“ (Šepetys 1982). Siekimas pranokti praeiti, suformuoti avangardistini

\footnotetext{
${ }^{1}$ Sociumas - teritorinè savaime atsinaujinanti žmonių bendruomenė, apimantigyvenvietės, regiono, krašto gyventojus (Vanagas 2003).
}

meno vaidmenị vertė ieškoti neịprastų išraiškos būdų bei priemonių. Taip buvo siekiama originalumo, ekstravagantiškumo, pasireiškusio dvejopai: vieni kūriniai buvo sąmoningai komplikuojami, idèjos perteikiamos itin sudètingai, įmantriai, neretai nedidelei profesionalų grupei ezoteriškai ir estetizuotai, demonstruojant rafinuotą intelektą. Buvo pasiektas labai aukšto profesinio lygio meistriškumas impresionizme, simbolizme, konstruktyvizme, sąmonès srauto literatūroje, ekspresionizmui buvo būdingas didelis vaizdo įtaigumas ir išraiškingumas, simbolizme mintis buvo reiškiama itin subtiliai. Kita tendencija krypo į primityvizmą, kai kada net ị infantilizmą, profanaciją (dadaizmas, tašizmas, populiarusis menas). Su šia tendencija, neigiančia tradicines vertybes, susijęs dekadentizmas. Judejjimo idèjos išreiškè žmonių interesų susvetimèjimą, urbanistinès aplinkos indeferentiškumą, beveidiškumą, individualizmą, žmogaus kaip visuomenès nario tapatybės praradimą. Vis labiau ėmé ryškèti kūrèjo ir ji supančios aplinkos atotrūkis, skirtingi, kartais net priešingi tikslai ir interesai. Atsirado formalizmo sąvoka, tai kūryboje tapo kasdieniu, ịprastu reiškiniu. Menas dažnai ėmè mègautis savo neprieinamumu plačiajai visuomenei, siekẻ pakilti virš sociumo, netgi tapo savitiksliu reiškiniu: „menas dèl meno“. Lozungas, kad "grožis vieną dieną pakeis pasaulï", tapo atgyvenęs ir visiškai nepopuliarus, nes pasaulis realiai pakeitè meną. Estetizmas buvo atmetamas kaip saloninio kičo ar saldaus, lengvo gyvenimo (angl. easy life) išraiška, minties paviršutiniškumo priemonè.

Pirmosios modernizmo srovės panašiai kaip klasicizmas ar romantizmas apėmé daugelį meno šakų. Tokios buvo impresionizmas, konstruktyvizmas, futurizmas. Simbolizmas ir siurrealizmas apèmè dailę, teatrą, grožinę literatūrą, modernas (secesija) - architektūrą ir dailę. Vèliau konkrečios modernizmo srovès buvo susijusios su viena ar kita meno šaka, žanru. Dailëje pasireiškè fovizmas, kubizmas, abstrakcionizmas, opdailè, populiarioji dailè, kinetinè dailè, hiperrealizmas, konceptualizmas. Architektūroje - funkcionalizmas, brutualizmas, metabolizmas, postmodernizmas, bionika, dekonstruktyvizmas, technicizmas (angl. hightech architecture), minimalizmas, filosofijos ir dailès simbiozès inspiruotas konceptualizmas. Atsirado ir èmé gyvuoti net ,architektūros be architekto“ sąvoka ir realizuoti pavyzdžiai.

\section{Lokalus konceptualusis prieštaravimų pradas}

Esminiai pasaulinio meno pokyčiai atsispindejo ir Lietuvos kultūroje. Sovietiniais metais modernioji 
dailè didžiulèmis kūrejuų pastangomis buvo dvigubai koduojama tarsi savotiška, labai subtili ir apgalvota paslëptos rezistencijos forma, rafinuota reakcija i svetimos valstybès primestą visapusišką ideologinị diktatą. Egzistavo neskelbtas pasipriešinimas dirbtinei socialistinio realizmo ideologijai, privalèjusiai būti paprastai ir suprantamai visiems - netgi jokio išsilavinimo ar pasirengimo neturintiems žiūrovams. Modernizmo naujovėms suvokti visuomet reikejo rimtesnių pastangų: vidinès mąstymo laisvès ir požiūrio alternatyvumo, platesnio kultūrologinio išprusimo, asmens vidinio pasirengimo priimti reiškinius kaip demokratinio pliuralizmo pasekmes. Visa tai visuomenei buvo sunkiai prieinama, nes iš esmès prieštaravo kuriamai proletariato diktatūrai ir žmonių sąmoneje formuojamai sovietinio gyvenimo ideologijai. Architektūros srityje, politiniais ịsakais supaprastinus stalinistinès epochos istorines formas, ideologijos atspindžiai nebuvo tokie ryškūs, kaip kitose meno srityse, tačiau technologijų atsilikimas padaré savo darbą. Statybų sektoriaus techninis ir meninis lygis neleido architektams pasiekti pasaulinio lygio tendencijų. Paradoksalu, kad šio laikotarpio statiniai, keliantys daug diskusijų kultūrologijos plotmejje, nekilnojamojo turto požiūriu išlaikè laiko išbandymus, jie pritaikomi naujomis paskirtimis, tebèra patikimų finansinių investicijų garantai (1, 2 pav.).

Šalies Nepriklausomybės atgavimas, staigus mąstymo laisves ir gyvenimo demokratijos proveržis suskaldè vertintojų ir kūrèjų meninị mąstymą ị kelias sunkiai suderinamas ir dažnai priešingas dalis. „Kartu su pertvarka iškilus naujoms veiklos galimybèms dailès pasaulyje pradėjo reikštis tiek kultūros decentralizacijos tiek ir savotiškos centralizacijos tendencijos“. „Dailès pasaulio „skaidymasis“ ir ịvairūs nesutarimai prasidèjo dar prieš Nepriklausomybès atgavimą, tačiau po 1990-ųjų profesinès dailininkų organizacijos veikla jau gana ryškiai skyrèsi nuo dailès gyvenimo specifikos, natūralios konkurencijos, „lygiavos" principu neišmatuojamos meninès vertès“ . „Kadangi ŠMC tapo pirmąja Lietuvoje vakarietiško tipo institucija, nuo pat pradžių aiškai deklaravusia naujos veiklos priemones bei tikslus, jos iniciatyvos negalëjo nesiskirti nuo LDS (Lietuvos dailininkų sąjungos) parodų veiklos, kuri kaip ir anksčiau buvo organizuojama atsižvelgiant tik $i$ tradicinių dailès šakų LDS sekcijų poreikius ir komisijų sprendimus" (Trilupaitytè et al. 2005). Technologijos raida padiktavo naujas vaizdo perteikimo priemones. Anot R. Dubinskaitès, „analizuojant daugybę video ir fotografijos darbų, sukurtų nuo 10-ojo dešimtmečio pradžios iki šių dienų, išsikristalizavo 6 skirtingi menininkų vaidmenys/pozicijos, kūrybos strategijos, kurios čia ịvardijamos metaforomis: narcizo, pojūčiu bandytojo, aktoriaus, etnografo, kontempliuotojo ir komunikuotojo" (Trilupaitytè et al. 2005). A. Tereškino nuomone, „žaismingai naudojantis popkultūra, popliteratūra ir kultūros teorija, <...> siekiama atverti skandalingo viešumo geneologiją, kolektyvinių ir individualių fantazijų normatyvumą bei masinès patirties suintyminimą dabarties Lietuvoje. Kokie viešumo im-

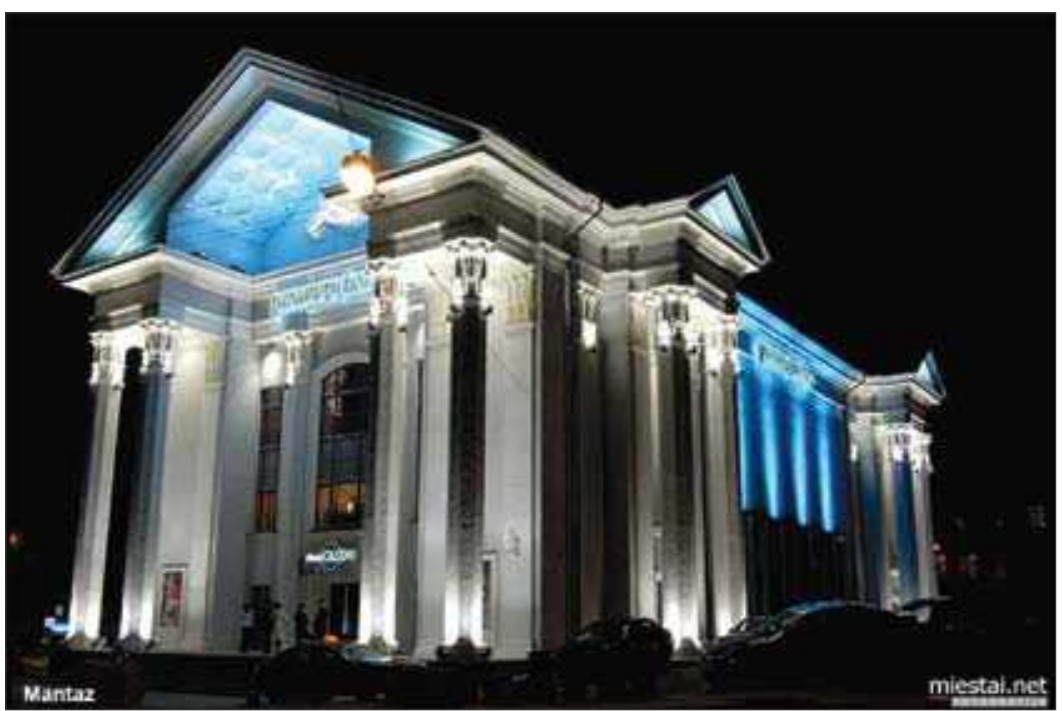

1 pav. Rekonstruotas „Pramogų bankas" (buvęs „Pergalès“ kino teatras)

Fig. 1. "Pramogų bankas" after reconstruction (former cinema "Pergalè")

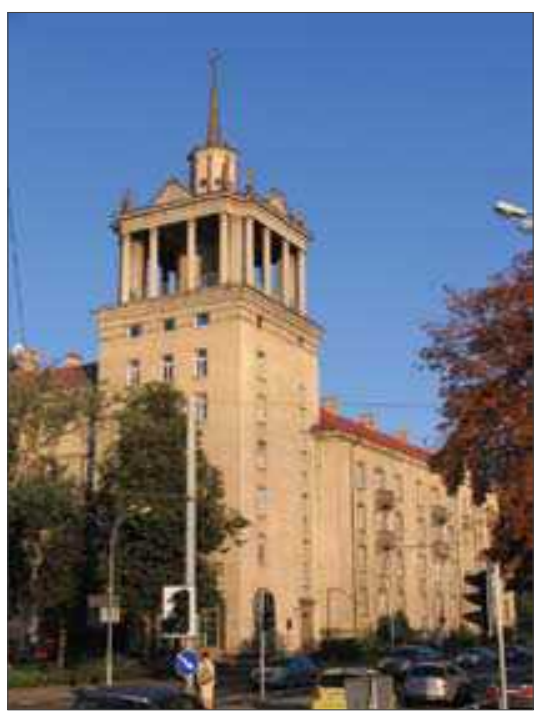

2 pav. Mokslininkų gyvenamieji namai Fig. 2. Housing estate "Mokslininku namai" 
peratyvai dabar yra patys svarbiausi? Ar skandalingo viešumo siekinys yra simptomatiškas šiuolaikinybei? Kokios esminès fantazijos yra užvaldžiusios masinès auditorijos akiratį?" (Trilupaityte et al. 2005). İsivyravo nuomonè, kad objektyvūs kultūros kriterijai išnyko ir èmè dominuoti tik tie apsukrūs žmonès, kurie savo draugystemis, ryšiais ar paslaugų mainais išpeša sau naudos. „Tačiau demokratinė visuomenè iš esmès skiriasi nuo totalitarizmo: anot rašytojo Kosto Ostrausko, $<\ldots>$ tiktai diktatūra paprastai skelbiasi turinti bei puoselëjanti sveiką, progresyvią visuomenę ir kultūrą. Tik ten, esą, viskas visada aišku, švaru ir tvarkinga - ne tik visuomeniniame gyvenime, bet ir kūryboje; tik ten, girdi, klesti tyros, moralios ir humaniškos idèjos bei jų prisotinti kūriniai. Žodžiu, tobulas law and order [ịstatymas ir tvarka]“ (Bučys 2008).

\section{Funkcinis prieštaravimų pradas}

Žmonijos erdvinị judejjimą suvokiant kaip vieną iš esminių aplinkos formavimosi prielaidų, pripažistant šio veiksnio lemiamą prioritetą prieš gyvenamosios vietos konkrečią lokalizaciją, išryškejja viešųjų erdvių svarba ir lemiantys jų parametrų veiksniai aplinkos formavimo procesuose. „Ar galejo architektūra atsirasti anksčiau, nei Žemèje įsivyravo sẻslus žmonių gyvenimo būdas? Šiuolaikinis mokslas atsako, kad ne“ (Vanagas 2003). Séslios civilizacijos atsiradimas ir jos raida natūraliai sukūrè prekinių mainų sritị bei prekybos fenomeną, o visa tai galejjo vykti tik esant vienokiems ar kitokiems pirklių judejimo keliams, kurie siejo skirtingus kraštus ir sudare prielaidas pasikeisti trūkstamais produktais. Istoriškai susiklosčiusi tipologinè šios srities sąvokų terminija patvirtina tai, jog viešosios erdvès (suprantant jas plačiąja prasme) iš esmès formavo, veikè ir nulèmé įvairiausių urbanistinių struktūrų atsiradimą, raidą, o kartais - reikšmés praradimą ar net ir visišką sunykimą. „Tam, kad miesto kultūra atsirastų ir ilgam ịsitvirtintų, reikejjo, kad tos teritorijos (terpès) apgyvendinimas taptų labai intensyvus, kad žemdirbiai, pajègdami patys prasimaitinti, galètų didelę dalị sukurtų maisto produktų perleisti kitiems" (Vanagas 2003). „<...> architektūros teoretikas Z. Gidonas pirmųjų urbanistinių teorijų $<$...> pradininku laiko popiežių Sikstą V (pontifikatas 1585-1590 m.), kuris suvokè miestą ne kaip formalų gatvių ir aikščių piešinį, bet kaip sudètingą kompozicinị - techninị organizmą, atliekantị utilitarias funkcijas" (Vanagas 2003). Miestai, atsiradę ir išsivystę kaip natūralūs žmonijos gyvenamosios aplinkos dariniai, ilgainiui èmé darytis verslo įrankiu. Siekiant suderinti viešųjų interesų apsaugą bei sukurti patrauklią aplinką investicijoms, iškilo plètros valdymo ir reguliavimo poreikis, automatiškai sukūręs funkcinị prieštaravimų pradą. Šių problemų suderinimas ir sprendimo kokybė realiai priklauso nuo kiekvienos šalies išsivystymo lygio.

\section{Technologinis prieštaravimų pradas}

Dailès kūrinių reprodukavimas, masinių informacijos priemonių atsiradimas, garso ir vaizdo aparatūros, elektronikos ir kibernetikos raida, kiti mokslo laimèjimai galutinai ištrynė ribas tarp menininko kūrëjo ir jo vertintojo. Tai tiesiogiai atsispindèjo meninèje kūryboje, atsirado naujų, visiškai alternatyvių ir kontrastingų iki šiol egzistavusiai klasikinei meno išraiškai kūrybinių ieškojimų, subrendo naujos vertybès, formavosi alternatyvūs judejjimai, iškilo netikètos filosofijos ir teorijos. Menas radikaliai èmè keisti savo pirmines prigimties formas. Amžinai maištinga kūrybos prigimtis atrado visai naujas veiklos sritis ir išraiškos priemones. Nuolatinis siekis atkreipti dèmesit, daryti įtaką, stebinti, šokiruoti - tapo esmine vertès siekiamybe, viršijusia estetines kategorijas, kurios būdavo charakteringos ir ištobulintos ankstesnèse formose. Meno sritimi tapo netikèčiausi, iki šiol nebūdingi šiai sričiai reiškiniai arba tiesiog - kasdienio gyvenimo objektai. Vis labiau sureikšminamas ir akcentuojamas kūrybos procesas, veiksmo siekis arba tiesiog pats veiksmas (angl. happening), fragmentuojamas tik atskiras momentas, neipareigojantis siekti meninio apibendrinimo, visumos, nepaisantis konkretaus galutinio rezultato kokybès arba dar daugiau - išvengiantis bet kokios materialios išraiškos. Atsirado vadinamasis tarpdisciplininis menas, susiejęs iki šiol atskirai besiplètojusias meno šakas. Profesionalusis menas visuomet vystėsi ir tebesivysto daug greičiau, negu evoliucionuoja visuomeninè jo samprata, ir tai sukelia daugybę naujų prieštaravimų.

\section{Geopolitinis prieštaravimų pradas}

Skirtingą aplinkos bei reiškinių vertinimą taip pat galima suvokti remiantis socialinemis „centro ir periferijos" prielaidomis. „<...> geometriné metafora „centras - periferija“ turi sudètingas daugiasluoksnių interpretacijų tradicijas (geografinis diskursas: miestas - kaimas, sostinè - provincija, geopolitinis požiūris: metropolija - kolonija, ekonominis orientyras: postindustrinès šalys - „trečiasis pasaulis“, tautinis likimo ženklas: Tẻvynè - tremtis, egzodas, kultūrinis 
rodiklis: pasauliniai mokslo ir meno židiniai - vietiniai kultūros ir mokslo centrai, valstybiniai ir net bažnytiniai matmenys: administraciniai centrai - provincijos, etc. $<\ldots . .>$ svarbiausia - erdvinès metaforos „centras periferija “ ittampa, istorinè sąveika ir dviejų dèmenų keitimosi vietomis paradoksas <....>. Enšteino terminu tariant, reliatyvūs, sąlyginiai, taigi, nuolat galintys pasikeisti vietomis lygiaverčiai semantiniai žmogiškos raiškos dydžiai <...>. Vakarykštis „centras“ gali tapti „periferija“ ir atvirkščiai - vakarykšte „periferija“ pavirsti „centru“, <...> istorijos bègyje keičiasi politinè priklausomybe், valstybinès propagandos orientyrai, ideologinio ir moralinio valdžios presingo metodai, viešpataujančių religijų poveikiai, tekstų komunikacijos priemonès, epochiniai kultūros kanonai, literatūrinès mados, talentų mastas ir gausa, laisvès ir humaniškumo „salos" visuomenès paklusnumo „liūne“, <...> keičiasi kultūros poveikis materialistiškai „pažaboto“ žmogaus savimonèje, <...> kultūra priešinasi dvasios sąstingiui, o menas ir literatūra pranašauja sąstingio laikinumą ir dvasinio praregèjimo galimybę, tegul ir utopišką žmogaus triumfą žodyje, spalvoje, garse, reginyje“ (Bučys 2008). „Istorinè ir geografinè Lietuvos valdymo „centrų“ kaita (Trakai $\leftrightarrow$ Vilnius $\leftrightarrow$ Krokuva $\leftrightarrow$ Varšuva $\leftrightarrow$ SanktPeterburgas $\leftrightarrow$ Kaunas $\leftrightarrow$ Maskva $\leftrightarrow$ Vilnius $\leftrightarrow$ Briuselis $\leftrightarrow$ Vašingtonas) niekad nebuvo panaikinusi ir negalèjo panaikinti transistorinio geografinès „periferijos“ nekintamumo. Lietuva, kaip žinia, visą laiką savo vietoje, kaip nuolatinè dvinarès metaforos „centras-periferija“ dalis, keičiasi tiktai geopolitinio „centro“ buveinë“ (Bučys 2008). „Tik toks binarinis požiūris gali išsaugoti kūrybiškai naudingas abipuses „,centro“ ir „periferijos“ itampas, kartu padèti tiksliai artikuliuoti dvipusius iššǔkius ir demokratines jų igyvendinimo galimybes laisvo dialogo atmosferoje. Nūdiené europocentrizmo euforija, be abejo, nèra palanki atvirai formuluoti tautinius interesus, vyksta platus „antinacionalistinis vajus“, tačiau akivaizdu, kad vietiniai ,antinacionalistai“ kaip visada, persistengia, norẻdami būti šventesni už šventuosius" (Bučys 2008). „<..> Lietuvos istorikų darbai <...> pažeidžiami dèl jų evoliucionistinio ir neoevoliucionistinio „futurizmo“ (Marx), (Tonbey), kai visa istorijos ir civilizacijos raida suvokiama kaip neišvengiamas judesys „,iš tamsios praeities“ - „t šviesią ateitį“, o tautos skirstomos pagal metafizinès pažangos grafiką i daugiau ar mažiau „atsilikusias", „vèluojančias“ ir pan. „<...> Diogenas Laertietis neužmiršta pridurti, kad Pitagoras, šiuolaikinès hermeneutikos (disciplinos, aiškinančios prasminius, bet savaime neaiškius veikalus. Senovès graikai apibrèžè kaip dievybės mįslingų pranešimų perteikimą žmonėms suprantama kalba, jos globėju buvo laikomas dievų pasiuntinys Hermis) ir Europos ezoterijos Tẻvas, būtent iš „barbarų“ „sužinojo visą slaptąjj mokymą apie dievus" <...>. Kažkokioje tolimoje „periferijoje“ gyvenančio žmogaus ar tautos nesuprantamas kalbejjimas tèra „bar bar bar bar...", tačiau vos atvykèlis iš tolimojo „centro“ išmoksta „barbaro“ kalbą, jis čia pat tampa nauju pašvęstuoju ir gauna naują „raktą “ $i$ universaliąsias būties paslaptis. Čia jau ižengiame i Levi Stroso ir jo sekejų revoliucines teorijas apie „civilizacijų lygiavertiškumą“. Bet <...> jokia teorija nepadès "civilizuotam žmogui“, kol jis neišmoks „barbarų“"kalbos <...>. Bent jau klasiku jis tikrai netaps, net šiuolaikinejje Europoje“ (Bučys 2008).

Kita vertus, iki šiol neturime mokslinių îrodymų, kas gi buvo tie „vandalai“ ir „barbarai“, kurie absorbavo suirusią Romos imperiją ir jos kultūrą. Labai patraukliai atrodo netiketa romantiko, istoriko, poeto Česlovo Gedgaudo teorija apie mūsų protèvių itaką Europos kultūros raidai: „Pas gudus (Ispanijoje, Pietu Prancūzijoje, Šiaurès Italijoje) tiktai romènai gyvena palaidą gyvenimą - pas vanduolius (suprask „vandalus") gi - net patys roménai sutvarkyti!“ „Barbarai“(„,varvarai - varuoliai“) moko „civilizuotus" <...>. Neblogai. Jei patys nustosime vartoti tuos nuvalkiotus žodžius ir sąvokas, Romos propogandos sukurtas, pamatysime, kas vyko iš tikrųjų: tai buvo dviejų pasaulèžiūrų kova - padorių, dievobaimingų lietuvių Arijų („arejų) prieš ištvirkèlius pagonis ( karo metu pagauti belaisviai, kuriais romiečiai ardavo laukus - „pagauniai“, lot. paganus - žemdirbys) Italijos miestelènus“ (Gedgaudas 1994).

\section{Kultūrinis prieštaravimų pradas}

„Mes visada nuoširdžiai tikèsime, kad tvirtos ir nepajudinamos tradicinès dvinarès būties struktūros viena dalis (svetimoji, kito) yra „blogesne““, „nenormali“, „laukine“, „pavojinga“ (lot. barbari infesti), „nešvari“, „neišsivysčiusi“", „bedieviška“, „neraštinga“, „nedora“, „netikusi“, „nepatikima“ (lot. infideli), „žiauri“, "gyvuliška“ (lot. bestiale), „barbariška“, „atsilikusi“ etc., o kita (savoji, mano, mūsų) - kur kas „geresnë“, „,normali“, „šviesi“, „švari“, „padori“, „,ne laukine““, ,civilizuota“, „dievobaiminga“, „kultūringa“, ,raštinga“ etc. Mary Douglas darbai atverè giliausias moralines dvinarès struktūros deformacijas kolektyvinèje pasąmonèje, susijusias su žmogaus ir genties instinktyvia 
savigyna „priešų apsuptyje“. Maža pasakyti, kad „ne mūsų" pasaulis yra pavojingas, būtina jausti, kad jis „nešvarus“, „nevertas kontakto“. O jei kontaktas vis dèlto įvyksta, būtina čia pat rituališkai nusivalyti, apsiplauti, stropiai dezinfekuoti „nešvariųjų“ paliestus indus ir daiktus. Akivaizdu, kad ir šiandien giluminès moralinès deformacijos glūdi žmogaus ir tautos instinktuose, jie bando „saugiai atsiriboti“ nuo pavojingų kaimynų su jų papročiais ir tikybomis“ (Bučys 2008). „<...> pasak Gintaro Beresnevičiaus, autsaideris ne tik atmeta kolektyvą (ir tuo pat metu iš jo demonstratyviai išvaromas), bet ir pasirenka atvirą likimą. Autsaideriai visada lieka šalia universitetų, akademinių sluoksnių, dailëje ar poezijoje - šalia premijų ir akademijų“, tačiau „išjudina naujas sroves, mokyklas, stilistikas“. „Ikiistorinis menininkas nupaišè Lasko (Lascaux, Prancūzija, 3, 4 pav.) olos sienose tokias $<\ldots>$ medžioklès scenas, kad linijos bei abstrahavimo stiliumi aplenkẻ Vakarų Europos tapytojus ne šimtais, o dešimtimis tūkstančių metų, jei skaičiuosim pagal teorinę meno modernejjimo skalę. Svarbiausia, kad olos piešinių meninè galia vienodai pribloškia ir meno ekspertus, ir mègèjus, ir profanus <...> (Bučys 2008).

Tautos kultūros ir jos visuomeninès sąmonès evoliucija, kaip ir pačios tautos raida, yra labai netolygi: „Tautos tapsmas buvo ir yra diskretinis (iš lot. diskretus, a um; iš discerno - atskirti, atriboti, atidalyti), tai yra netolydus, nuolat nutrūkstantis ir vèl susimezgantis, žiauriausiai nutraukiamas ir vèl stropiai sujungiamas, metodiškai diskredituojamas ir vèl atkakliai ginamas permainingas procesas. Tautos tapsmas kartu ir herojiškas ir tragiškas procesas. Kaip tik dèl to <...> visada labai lengva prikišti „informacines duobes“, kuomet tauta $\langle\ldots>$ nei raštu, nei valstybiniais aktais nerodo jokių gyvybės požymių, tarsi jos nebūtų buvę. Dèl to ypač pažeidžiami visų laikų romantinès patriotinès pakraipos mèginimai parodyti tautos ir jos kultūros tapsmą kaip nenutrūkstamą, vis stiprèjantị procesą nuo seniausiụ laiku iki mūsu dienu tautinio idealo. $<\ldots>$ įmanoma analitiškai atsekti, kokios jẻgos iš kokių "centrų", tautai prabudus, stengèsi aiškinti ir „moksliškai“ ịteigti, kad tauta ką tik gimè, mažytè ir kvaila, nekultūringa ir necivilizuota, taigi jai reikalinga seno galingo „centro“ akyla priežiūra ir „,atsilikusiai periferijai“ tinkamas liokajiškas apmokymas, vidutiniško lygio švietimas ir visiems prieinami masinès gamybos pasilinksminimai, kad paskui kiečiau miegotų. Tai nereiškia, kad „informacinių duobių“ tarpsniais nieko nevyko. Priešingai - vidinis etnosimbolizmo nutviekstas vyksmas gali išryšketi visur ir visada, jeigu išmoksim skaityti net iš tuščio lapo“ (Bučys 2008). Nors tai vyksta visame pasaulyje, tačiau ypač ryškiai mes tai jaučiame savo pačių istorijoje.

\section{Juridinis prieštaravimų pradas}

Žinant, jog Lietuvoje kaip ir daugelyje pasaulio šalių privačią nuosavybę gina Konstitucijos nuostatos, tik asmeninès erdvès negali būti visuomeniškai prieinamos ar kitaip demonstruojamos be jų savininkų sutikimo ar valstybinių juridinių nuostatų (kratos orderių ar pan.). Visa kita aplinka daugiau ar mažiau gali būti priskiriama bendrojo naudojimo kategorijoms. Ši sistema, susijungusi į visumą, sudaro urbanistinius erdvių formantus, kitaip tariant karkasą - „aktyviausią gyventojų masinès veiklos procesų teritorinị telkinị, intensyviausiai ịsisavintą erdvę. Karkasą formuoja pagrindinès magistralès, komunikacijų mazgai, su jais susiję miesto statiniai - visuomeniniai, verslų, komercijos ir kiti unikalūs kompleksai, pritraukiantys masinius lankytojų srautus" (Vanagas 2003). Iš esmès miestus formuoja ne tik subjektyvūs, meniniai bei kultūriniai veiksniai, bet ir objektyvios aplinkybės: „Plačių gatvių tiesimas, vandentiekio, kanalizacijos, dujų tiekimo tinklo ir sistemų statyba, parkų kūrimas, viešojo transporto diegimas $\langle\ldots\rangle$ - štai pagrindiniai realūs urbanistikos puoselètojai“" (Vanagas 2003).

Viešųjų erdvių sudaromoji dalis, be kurios neįsivaizduojamas šiuolaikinis urbanistinis visos šalies, konkretaus miesto karkasas, yra transporto tinklas: vieškeliai, keliai, gatvès, šaligatviai, greitkeliai, aplinkkeliai, tiltai, tuneliai, aikštès, alèjos, skverai, esplanados, parkai, nacionaliniai parkai, rezervatai, draustiniai, valstybiniai miškai, vandens telkiniai, krantinès, kurortai, regyklos, miestų interjerai, pastatų prieigos ir jų interjerai. Natūralu, kad kiekviena iš čia išvardintų erdvių tapo menininkų interesų objektais, naujais kūrybos iššūkiais, naujomis kūrèjų ir visuomenès sąmonių sąlyčio, estetinès komunikacijos taškais. Esminis skirtumas tarp visuomenès ir kūrejjų sovietiniais metais ir dabar yra grindžiamas iš esmès skirtingu dalyvavimo šiuose procesuose principu. Totalitaristinè ideologija vienareikšmiškai nurodinèjo meno kūrimo būdus, siekdama kultūrą dirbtinai priartinti prie masinès sampratos ir padaryti prieinamą bet kokio išsilavinimo žmonėms, o demokratijos sąlygomis visuomenei suteikta laisvè pačiai pasirinkti reikalingus dvasinius kriterijus. Tokiu atveju sociumo pasirengimo veiksnys tampa svarbiausias, nes kūrẻjų pasiūla tampa absoliučiai beribè, apibrèžta tik taikaus sambūvio principais 


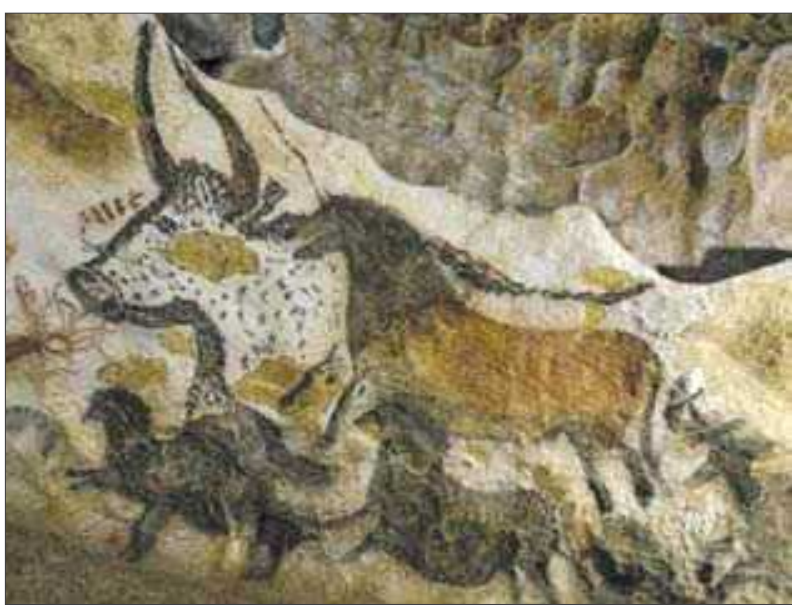

3 pav. Lasko (Prancūzija) urvo piešiniai

Fig. 3. Drawings in the cave Lasko (France)

bei moralès nuostatomis pagrịstais oficialiais valstybès istatymais, tačiau labai skirtingai interpretuojamais. Tokiai meninei situacijai įvertinti jau neišvengiamai reikalingas specialus pasiruošimas ir išsilavinimas kaip ir bet kurioje kitoje gyvenimo srityje. Visuomeninis ryšys ${ }^{2}$ ir visuomenès dalyvavimas planavimo procesuo$\mathrm{se}^{3}$ ir pan. tampa kūrybą realiai reglamentuojančiais veiksniais, o valdžios kaip anksčiau iprasto vienintelio sprendžiančio absoliuto ịsikišimas tampa neveiksmingas. Naujosios aplinkos formavimo problemos labai konkrečiai išryškejja hinterlende 4 ir visiškai atitinka „vietų teoriją ${ }^{\text {“5 }}$.

\footnotetext{
${ }^{2}$ Visuomeninis ryšys - tarpusavio ryšio jausena, tikslų bendrumas, žmonių grupès solidarumas (kartais lydimas atskirumo jausenos), sukeliantis jos nariu lojalumą tos grupés sukurtoms ir respektuojamoms normoms ir vertybėms. Pasireiškia visuomeninių institucijų sistemoje (pvz.: tarpusavio pagalba, bendradarbiavimas, visuomenès nuomonè). Tiesiogiai susijęs su bendruomenès kultiniu ir visuomeniniu vienarūšiškumu; susidaro taip pat ir kaip žmoniu erdvinio artumo pasekmè. Visuomeninio ryšio tipas - kaimynystès ryšys (Vanagas 2003).

${ }^{3}$ Visuomenès dalyvavimas planavimo procese. Pagal LR teritoriju planavimo įstatymą visi teritorijų planavimo dokumentai turi būti svarstomi viešai. Visi LR fiziniai ir juridiniai asmenys turi teisę susipažinti su rengiamais ir patvirtintais teritorijų planavimo dokumentais, gali reikšti pastabas, pasiūlymus, o labiausiai su planuojama teritorija susiję - reikšti pretenzijas. Vakarų šalyse visuomenès dalyvavimas (public participation) yra kultivuojamas nuo seno ir plačiai, yra nusistovejusios specialios formos ir metodikos (Vanagas 2003).

${ }^{4}$ Hinterlandas - rajonas, kuris yra artimas centrui (pramoniniam, prekybiniam centrui, uostui ir pan.), pasižymi trauka $\mathfrak{i} j \mathrm{ji}$ (Vanagas 2003).

${ }^{5}$ Vietų teorija - teorija, tirianti jègas, kurios lemia ịvairaus profilio įstaigų išsidèstymą. Jos poskyris - tai centrinio miesto (arba centrų) teorija, nagrinejanti teritorijos centrų susidarymą (Vanagas 2003).
}

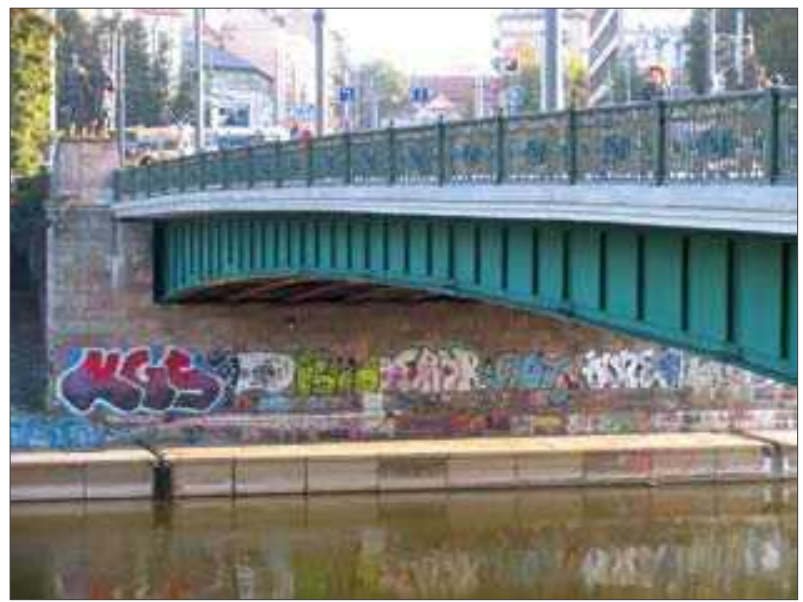

4 pav. Šiuolaikinè spontaniškoji miestu grafika

Fig. 4. Graffiti in contemporary city

\section{Būdingi prieštaravimai viešųjų erdvių formavimo pavyzdžiuose}

Viena iš pirmųjų naujojo meninio mąstymo apraiškų ir artefaktų ${ }^{6}$ tapo skulptoriaus Gintaro Karoso įkurto Europos parko (5 pav.) idèja. Tęsianti jau anksčiau, dar sovietiniais metais valstybės inicijuotų ir realiai pradètų kurti skulptūros parkų tradiciją, ši veikla buvo komercializuota, už įejimą i teritoriją pradètas imti mokestis (nors realios tvoros nebuvimas miške leido ir kitus „apžvalgos“ variantus). Nuolat pateikiama informacija masinèse informacijos priemonèse, garsių pasaulinio lygio menininkų dalyvavimas pleneruose, netgi edukacinès erdvès ịkūrimas - visa tai bylojo apie naujo požiūrio ị meną raidą. Šiuolaikinis menas ir menininkai - jau nebe tie kuklūs praeities genijai, kurie dažnai net savomis lěšomis, prastomis buities ir darbo sąlygomis, aukodami asmeninę gerovę ir sveikatą, kūrẻ genialius šedevrus, tyliai laukdami visuotinio pripažinimo, arba taip ir numire išsekę, visiškame skurde. Naujieji kūrèjai užèmẻ aktyvią gyvenimo poziciją, naudojosi rèmėjų, stipendijų, programų arba fondų lèšomis, naujausiomis techninèmis atlikimo priemonèmis. Dar daugiau - jie tarsi nustate principus naujai gyvenimo ir veiksmo estetikai, drąsiai ir kartais net iššaukiančiai paneigę ir sumenkinę ligšiolinius klasikinius bandymus.

\footnotetext{
${ }^{6}$ Artefaktas - medžiaginis žmonių sukurtas objektas (užstatymas, infrastruktūra, statybų technika, transportas, telekomunikaciniai ryšiai). Tai pirminiai artefaktai, antriniai - papročiai, normos, taisyklès, simboliai (Vanagas 2003).
} 
Natūrali gamtos apsuptis suteikia puikų foną meniniams eksperimentams, urbanistinio konteksto laisvè nekelia jokių estetinių pretenzijų. Pagrindinė šio tipo erdvių prieštaravimų sritis - materialaus išlikimo klausimai. Nuolatinè, jèga brukama komercializuota reklama spaudoje, radijo ir televizijos laidose jau tampa nebe informacijos ar meno propagandos įrankiu, bet veikia priešingai - sukelia atvirkštinę atmetimo reakciją. Perdèm ịkyriai brukamos prekès dažniausiai būna nelabai pastebimos arba net mažai kam reikalingos.

Sovietiniais metais buvo ir priešingų variantų nesavanaudiškos asmeninès iniciatyvos pastangomis sukurta Viliaus Orvido sodyba Salantuose šiuo metu yra gerokai užmiršta ir apleista, tačiau išeivijoje vertinama kaip pasaulinio lygio reiškinys. Avangardistas filmų kūrèjas Jonas Mekas teigia: „Brancusi, Moore, Smithson - svarbūs dvidešimtojo amžiaus skulptūros istorijoje. Bet Orvidas yra lygiai svarbus. Tu stovi tarp visų tų akmenų ir jauti tokią didelę žmogaus jègą, tokị neapsakomą atsispyrimą prieš visas totalitarines jẻgas. Ateis laikas, kai pasaulio meno studentai iš Japonijos, Amerikos ir Paryžiaus plauks ị Salantus, kaip jie plaukia ị St. Michel, Taj Mahal ar Stonehenge“ (Bučys 2008) (6 pav.).

Atsvara sovietiniais metais vyravusiai ideologizuoto meno koncepcijai, ją paneigiantis, ironizuojantis Grūto parkas ịkurtas verslo idèjos pagrindais. Ši viešoji erdvė tapo ypač patraukli užsieniečiams ir atkūrus Nepriklausomybę gimusiam jaunimui, tik iš laikraščiu ir radijo ar televizijos pranešimų girdejjusiems apie to laikmečio realybę. Žmonèms, sovietiniais metais realiai gyvenusiems šioje dirbtinai ideologizuotoje aplinkoje, Grūto parkas sukelia visai kitokias asociacijas. Netikèta tai, kad gana ironiška ideja pagrịsto parko

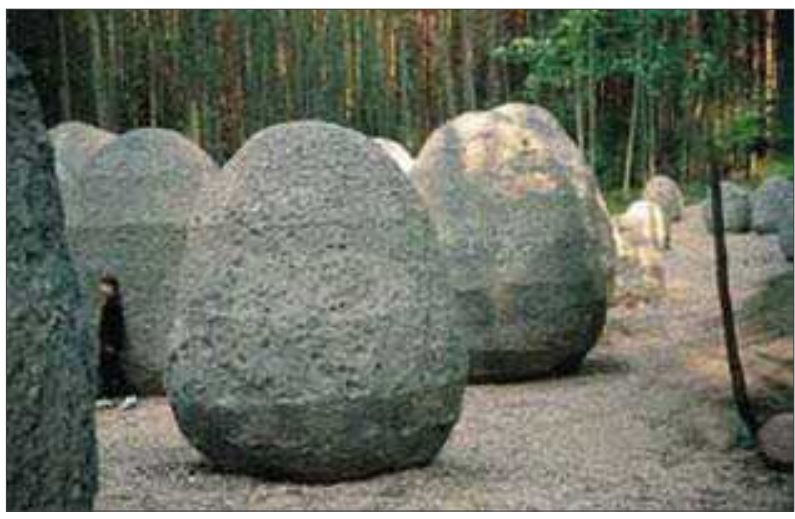

5 pav. Profesionaliai angažuotas Europos parko skulptūrų dirbtinumas

Fig. 5. Artificially engaged professional attempts to create "Europa" park of sculptures sukūrimas šiuolaikinès Rusijos tarptautinëje politikoje pateikiamas kaip teisingo Lietuvos bendradarbiavimo su ja ir išlikusios sovietinių metų kultūros problematikos sprendimo etaloninis pavyzdys, originali išeitis iš keblios ideologinès situacijos.

Visais atvejais menas kūrèjų pateikiamais sprendimais atlieka vieną iš savo pagrindinių užduočių - sukelia išgyvenimus, veikia žmonių sąmonę, gyvenimo raidą, formuoja viešųjų erdvių aplinką. Dažniausiai objektai yra suprantami ir vertinami sąmoningai ar nesąmoningai lyginant, ieškant analogijų, stengiantis juos klasifikuoti sąmoneje ir pritaikyti prie jau anksčiau žinomų, visuomenès aprobuotų archetipų ${ }^{7}$. Kultūrino veiklos nuoseklumo, perimamumo ideja visuomet yra aukštesnè raidos kategorija negu paprasčiausias paneigimas ar net visiškas sunaikinimas. Nors Romos kultūros vertybè - griuvèsiai, atsiradę kiekvienam naujam cezariui naikinant prieš tai valdžiusiojo darbus ir jamžinant savuosius, Helsinkio centre yra priešingų pavyzdžių. Iki šiol vienoje iš pagrindinių šalies viešųjų erdvių, prieš pagrindinę šventovę - katedrą - yra išsaugotas buvusio šalies užkariautojo caro Nikolajaus bronzinis paminklas.

Tik per plauką Vilniuje išliko socialistinio realizmo plastiniai pavyzdžiai ant Žaliojo tilto (7, 8 pav.). Naujosios kartos meno atstovai taip pat nèra abejingi šiai aplinkai ir nuolat savaip papildo ją grafitais arba tiesiog užmauna skulptūroms kartonines dėžes ant

Archetipas [gr. archetypon < arche - pradžia + typos - pavyzdys] - simbolio, ženklo, turinčio konkrečią socialinę erdvinę reikšmę, pirmavaizdis, susikūręs kolektyvinèje pasąmonèje ir leidžiantis atpažinti bei identifikuoti erdvines, socialines ir gamtines realijas urbanistinių objektų ịvaizdžiuose (Vanagas 2003).

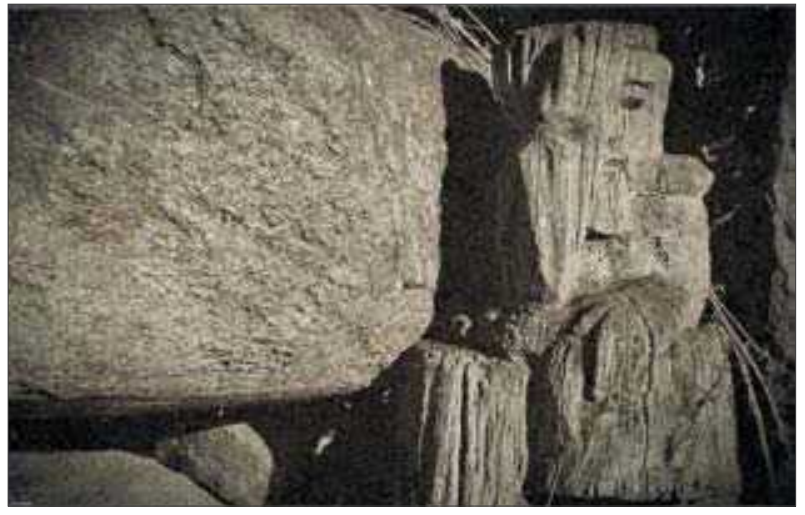

6 pav. V. Orvido sodybos estetikos natūralus betarpiškumas Fig. 6. Natural immediacy of the sculptural environment in the V. Orvidas' grange 
galvų. Labiausiai tilto estetiką darko ideologinès kovos su sovietinių švenčių progomis atsirandančiomis provokacijomis pasekmès - ant akmens dažais užterlioti užrašai.

Lenino paminklo nukèlimas nuo postamento tapo chrestomatiniu visos Rytų Europos sovietinès sistemos byrejjimo simboliu, iki šiol demonstruojamu ịvairiose masinėse informacijos priemonėse ( 9 pav.).

Aukščiausia tarpusavio nesusikalbejjimo ir sampratos atskirties išraiška tapo Lukiškių aikštės sutvarkymo konkurso etapai. Seimo nutarimas, kaip politinis bei juridinis dokumentas, išreiškęs intuityvią visuomenès valią - centrinę miesto bei visos šalies erdvę paversti laisvès išraiškos simboliu vietoje buvusios ideologizuotos viešosios erdvès - kol kas taip ir liko neigyvendintas (10 pav.). Pažangios minties patriotinès jègos, veikusios pogrindyje sovietiniais metais ir sudariusios prielaidas Sovietų Sąjungos griūčiai, nesurado tiesioginio, nuoširdaus ir priimtino atgarsio menininkų vaizduotėse. Pasigirdo net radikalių profesionalų nuomonių apie pačios erdvès fizinių parametrų neatitiktị keliamiems tikslams. Laikui bėgant iš priemiesčio pievos evoliucionavusi turgaus aikšte, iki šiol išlikusi kaip viešoji erdvè - žaliasis miesto plotas, kelia ịvairias urbanistines asociacijas, tarsi tai galètų būti dar vienas puikus sklypas naujoms statyboms. İvertinus galimų architektūros objektų ideologinę ir tipologinę prigimtị, kyla rimtų abejonių dèl galimos tokio objekto funkcinès paskirties šioje ypatingoje teritorijoje. Tradiciškai aukščiausius žmonijos siekių ir svajonių idealus išreikšdavo bažnyčios statyba, tačiau net ir šis objektas jau yra

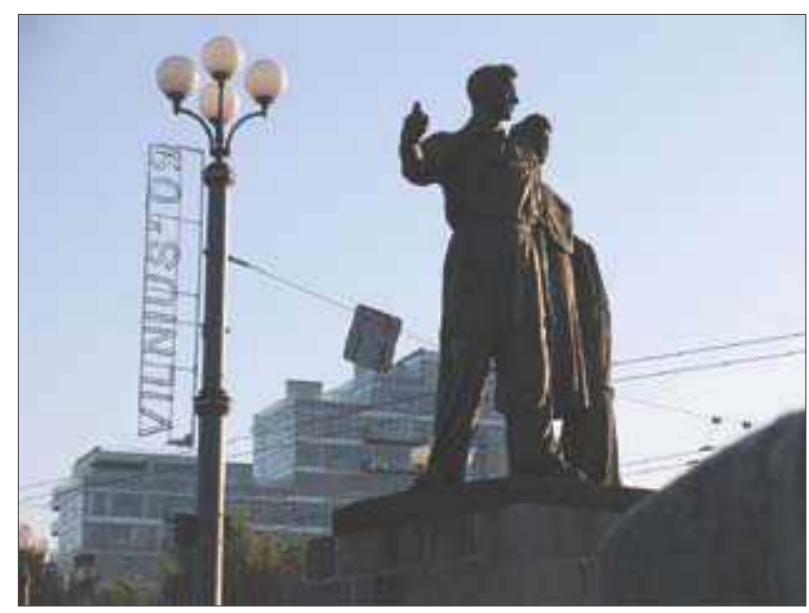

7 pav. Žaliojo tilto plastiniai akcentai

Fig. 7. Sculptures of Green Bridge

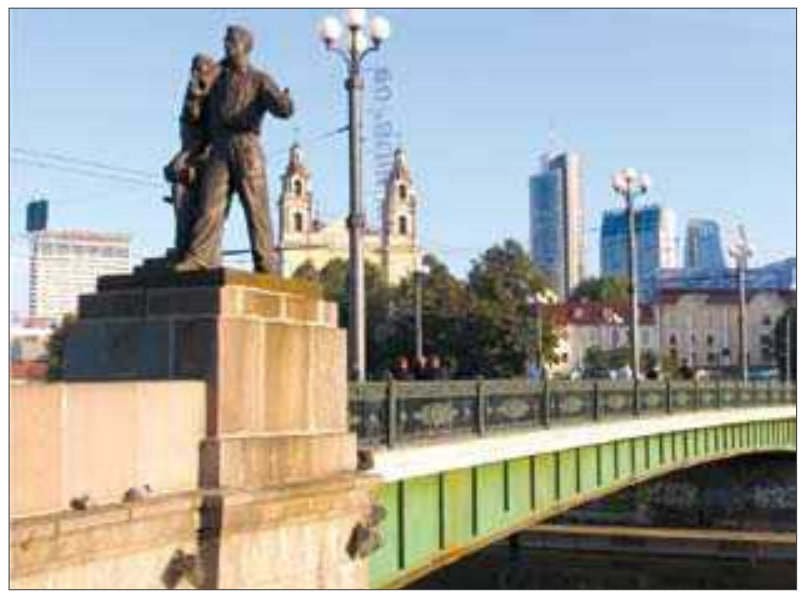

8 pav. Žaliojo tilto kontekstas

Fig. 8. Context of Green Bridge

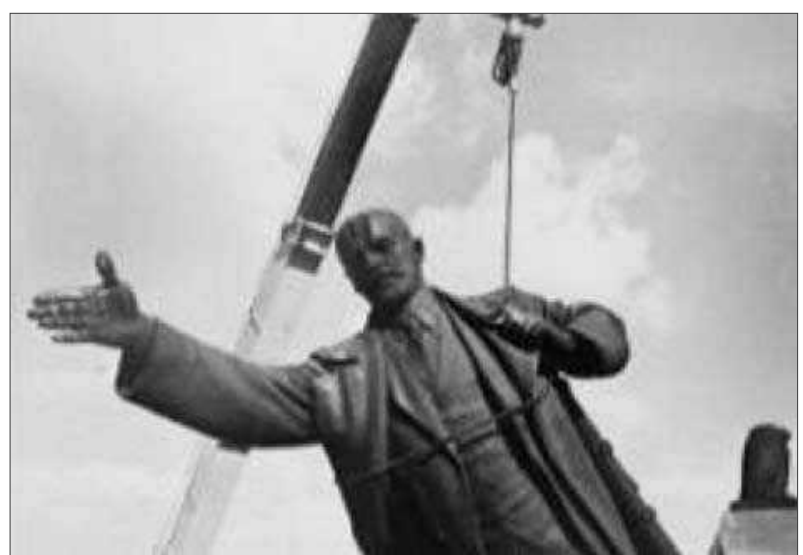

9 pav. Lenino paminklo išmontavimas Vilniuje

Fig. 9. Demounting of the Leninas Monument in Vilnius

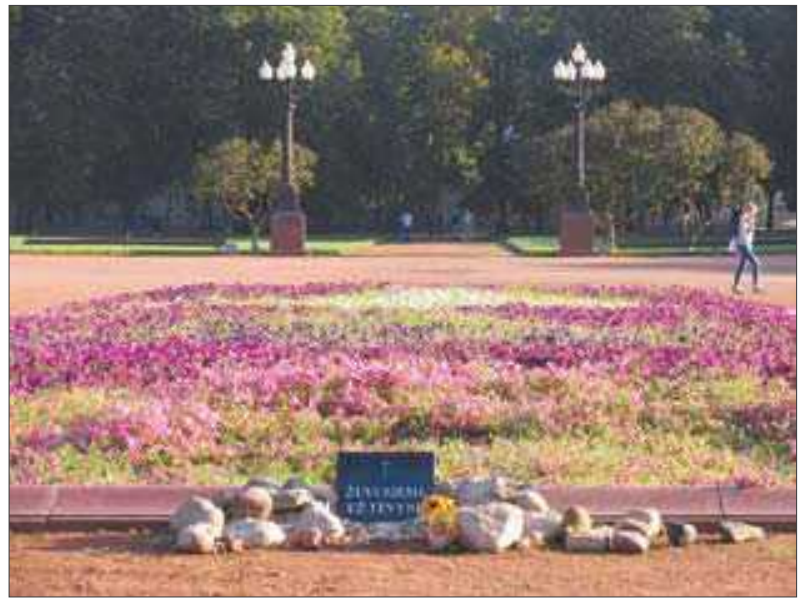

10 pav. Dabartinis Lukiškių aikštès vaizdas

Fig. 10. Contemporary view of the square Lukiškès 
netoliese realizuotas. Suvokiant moderniosios kultūros nevienareikšmiškumą, jos finansavimo šaltinius ir galimybes, net ir koncertų salès bei meno parodų objektas tokiose erdvèse kelia daugiau klausimų negu pateikia atsakymų (tai liudija Taurakalnio objekto konkursas, kuriame kultūra jau tampa tiesiogiai priklausoma nuo verslo diktato). Nemažiau abejonių kelia ir galimas urbanistinis, nepriklausomas nuo objekto paskirties, pastatymas, nes ši teritorija iš esmès yra užbaigta pagal tuometinị aplinkos supratimą, suformuota kaip vientisa erdvè su įvairiais laikotarpiais aplink užstatytais objektais. Antra vertus, argi gali būti mieste per daug žaliųjų plotų? Negi pradèsime diskutuoti apie per didelị ir nesuformuotą Kalnų, Vingio parkus, Katedros aikštės kaimynystėje esančius plotus ir pan. Ne visuomet architektūriniai, skulptūriniai ar kiti grynai profesine logika pagrịsti veiksmai gali padèti išspręsti susiklosčiusias visuomenines, politines ar socialines problemas. Panašus likimas, ko gero, laukia viso buvusio Profsąjungu rūmų pastato ant Tauro kalno, nors konkurse ir buvo pateiktos pakankamai originalios ir profesionalios esminio tūrio, ịaugusio ị miesto panoramas, išsaugojimo idejjos. Daugelis Lietuvos ir užsienio pavyzdžių įrodé, kad kartais didesnę meninę pridètinę vertę galima pasiekti esamas struktūras integruojant ì naują audiní, o ne objektą tiesiog nušluojant nuo žemès paviršiaus ir pradedant darbus pagal tabula rasa metodiką - visiškai iš naujo (11, 12 pav.).
Prieš keletą metų Vilniaus miesto politikai, ieškodami naujų patrauklių investicijoms idejjų, atsigręžè ì pagrindinę miesto kompozicinę aši - Neries upę. Ivairūs konkursai ir kūrybinès dirbtuvès išryškino užmirštą šios aplinkos potencialą. Krantinèse, pievoje šalia Baltojo tilto, kitose vietose pradètos rengti ịvairios meninès akcijos, koncertai, miesto šventès, oro balionų varžybos ir pan. Kulminacija tapo tarptautinès Gugenheimo-Ermitažo muziejaus kviestinių architektų varžytuvès, išjudinusios viešąją nuomonę bei inspiravusios diskusijas apie nacionalinio ir užsienių meno tarpusavio santykị ir sąveiką. Pagrindiniu šiuo metu pačiame miesto centre esančios tuščios pievos - viešosios erdvès - akcentu turètų tapti didelis, futuristinès, drastiškos išraiškos pastatas (13, 14 pav.).

Savo išskirtinumu ir unikalumu jis privalètų atlikti trejopą vaidmenị: tapti reikšminga, pasaulinio lygio meno kūrinių ekspozicija, unikaliu architektūros objektu, miesto centro viešosios erdvès formantu. Ivertinus ir tai, kad šalia numatomas naujasis tiltas (tebeanalizuojama galima jo urbanistinè trasa), šiuo metu esanti didžiulè atvira erdvè gali sumažèti iki minimumo. Paskelbus dienraštyje „Respublika“ apie kontraversišką Pigiausios skulptūros konkursą, kaip viešu atsaku it pastaruoju metu Neries upès krantinèse politine iniciatyva instaliuotus tris plastinius objektus, sukèlusius prieštaringą gyventojų reakciją (15 pav., a, b, c), šio straipsnio autorius pasinaudojo galimybe grafiškai išreikšti savo požiūrị i meno ir viešosios erdvès santy-

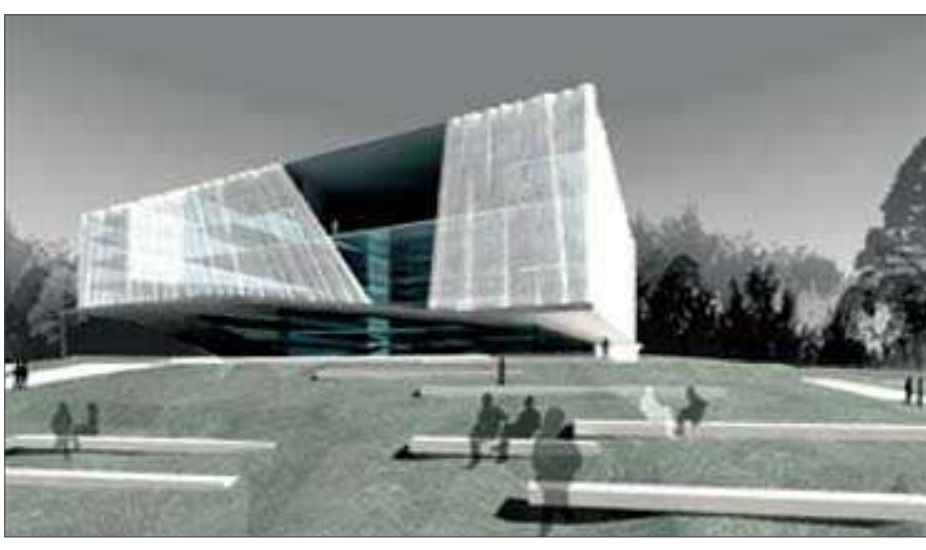

11 pav. Visuomeninio pastato ant Tauro kalno konkursinis projektas (aut. UAB "Vilniaus architektūros studija“. Archit. K. Pempè, A. Pliučas, G. Gečaitè, L. Jančytè, N. Baran, J. Dagelis, D. Kisielius, V. Kutaitè, I. Lukauskas, V. Lukoševičius, G. Jurgelevičius)

Fig. 11. Entry to architectural competition for the public building on Tauras Hill (authors: UAB "Vilniaus architektūros studija".

Archs. K. Pempè, A. Pliučas, G. Gečaitè, L. Jančytè, N. Baran, J. Dagelis, D. Kisielius, V. Kutaitè, I. Lukauskas, V. Lukoševičius, G. Jurgelevičius)

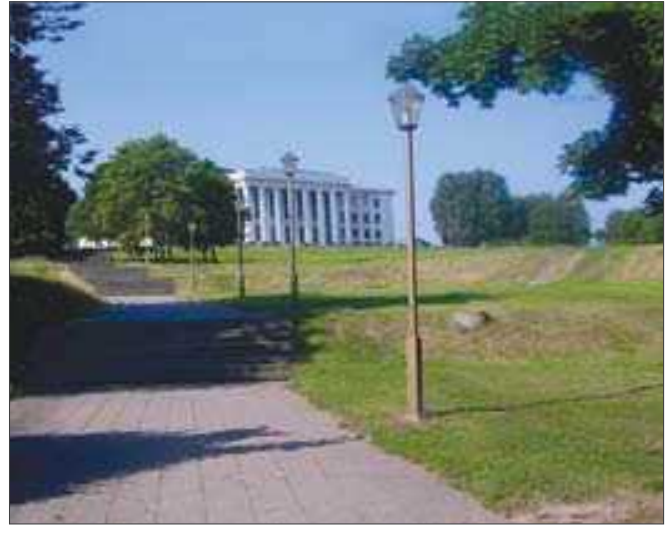

12 pav. Šiuo metu esančio pastato ant Tauro kalno vaizdas

Fig. 12. Contemporary view of the building on Tauras hill 


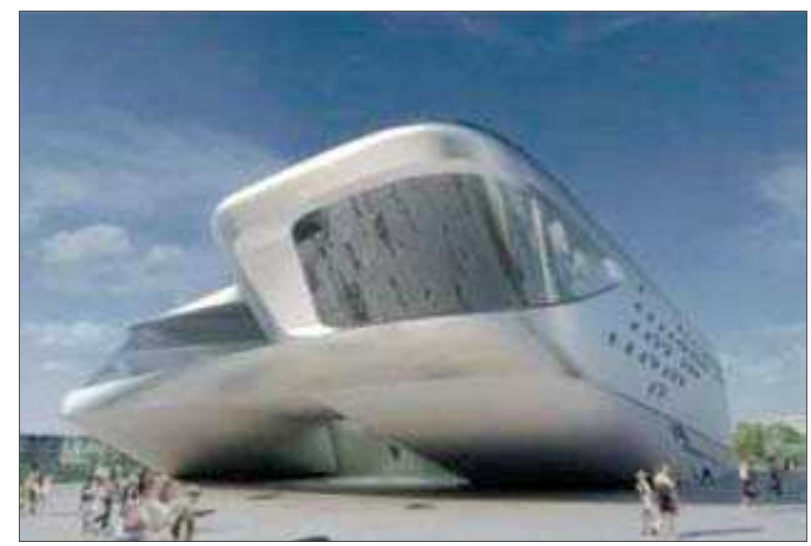

13 pav. Gugenheimo-Ermitažo muziejaus vizija Vilniuje (archit. Zaha Hadid grupès vizualizacija)

Fig. 13. Vision of Guggenheim-Hermitage Museum in Vilnius (visualization of arch. Zaha Hadid group)
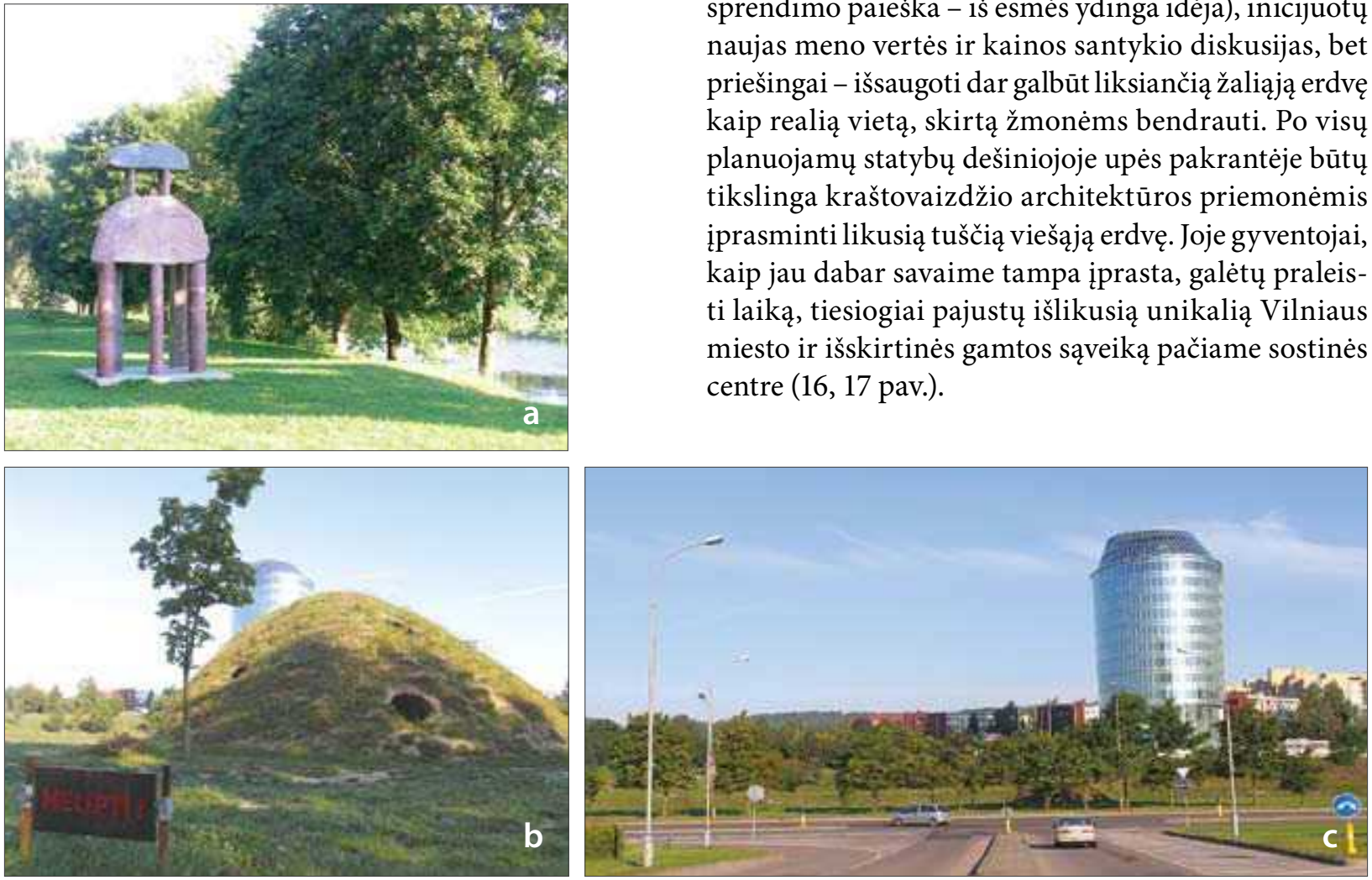

15 pav. Vilniaus - Europos kultūros sostinès - proga sukurti meno akcentai Neries pakrantèje (aut. V. Urbanavičius, M. Navakas, R. Antinis). „Puskalnis“, stovėdamas gatvès ašyje, gali trukdyti ateityje šioje vietoje nutiesti tiltą i Žvèryną (a, b, c)

Fig. 15. Sculpures created on the Neris riverside for Vilnius - the capital of European culture (authors: V. Urbanavičius, M.Navakas, R. Antinis). "Puskalnis” erected on the street axis could block the future bridge to Žverynas (a, b, c) 


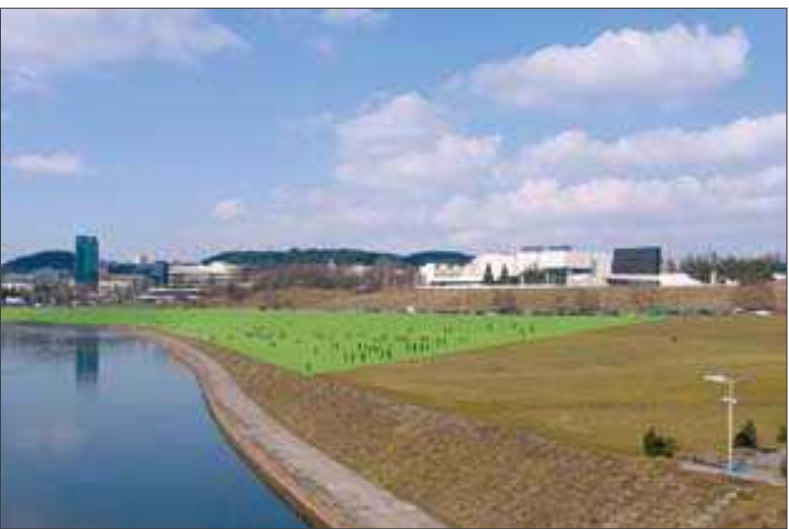

16 pav. Natūralios gamtos išsaugojimo idejja Neries krantinès viešojoje erdvèje (archit. G. Čaikauskas)

Fig. 16. Idea of preserving natural public space on the Neris riverside (arch. G. Čaikauskas)

Studentų miestelio Saulètekio alejjoje viešosios erdvės sutvarkymo konkurse pateikti šalia pėsčiųjų tako esančios aikštelès humanizavimo projektai. Premijuotuose darbuose aplinka organizuojama skirtingos išraiškos plastinèmis priemonèmis bei papildomais mažosios architektūros elementais: suoliukais, šviestuvais ir pan. I vietos nugalètojai pasiūlè labiau iprastą - plastinį akcentą, o II vietą laimejjusiame darbe pasiūlyti modernių technologijų sprendimai, kuriems suteikta simbolinè prasmè. Pagrindinis idèjos akcentas - skulptūrinè kompozicija „Mokslo laikrodis“, atspindinti naujausias technologijas. Iš ekranų suformuotas stačiakampis organizuoja ir îprasmina šiuo metu esantị anemišką plotą, likusị demontavus sovietinių metų monumentą. Aikštės piešinys leidžia sukurti saulès laikrodžio sistemą, gali būti panaudojamas elektroninei laiko skalei ir t. t. Koncentriškai aplink akcentą išdèstyti dvylika suoliuku išreiškia dvylikos mènesiu ideja, kompozicijoje dalyvauja esantis miško masyvas, pavieniai medžiai (18 pav.).

Centrinès Liublino (Lenkija) viešosios erdvès Skver Litewski išvystymo tarptautinès architektūrinès dirbtuvès atskleide, jog viena iš pagrindinių problemų visuomet yra socialinis užsakymas. Pateikti sprendimai irodé, kad iš esmès situacija, susiformavusi Vilniaus Lukiškių aikštès konkurse, yra simptomatiška, ji kartojasi neprklausomai nuo daugelio aplinkybių. Visuomet tokiose situacijose susiformuoja du konceptualūs kraštutinumai, o kiti projektai išsidèsto tarp jų. Radikaliausias sprendimas - kiek galima urbanizuoti esantị laisvą plotą, îrengiant antžemines ar požemines

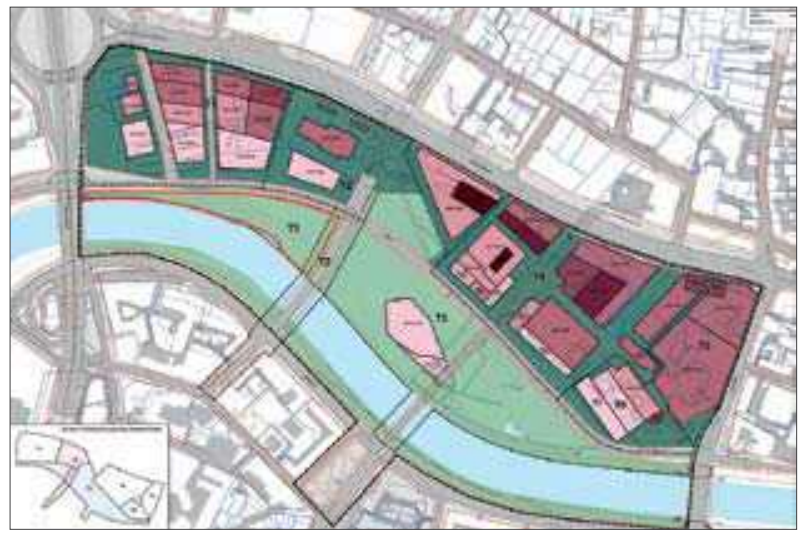

17 pav. Siūloma viešosios erdvès (archit. G. Čaikauskas) padètis urbanistineje konceptualaus planavimo schemoje ("Vilniaus planas", arch. S. Motieka)

Fig. 17. Proposed location of public space (arch. G. Čaikauskas) in conceptual planning scheme ("Vilniaus planas", arch. S. Motieka)
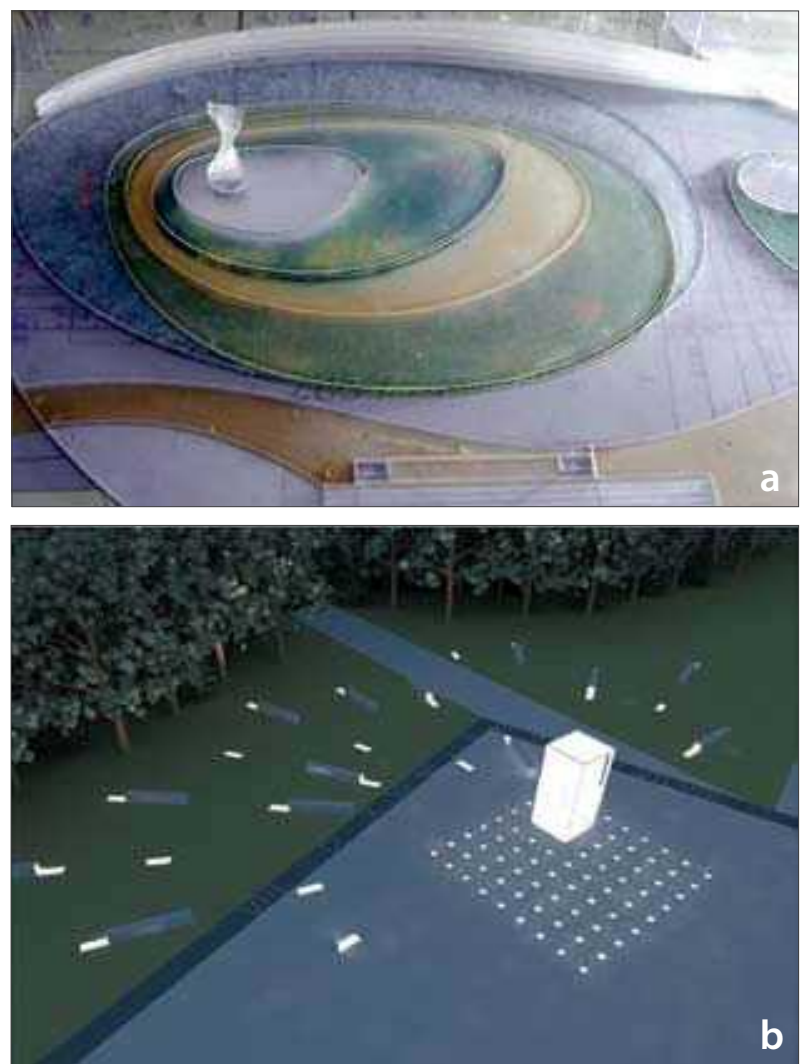

18 pav. Kompozicijos „Mokslo laikrodis" konkursiniai darbai:

a) I vieta (aut. "Naujoji architektūra ir grafika“);

b) Il vieta (aut. „Architektūros linija“)

Fig. 18. Entries for architectural competition "Science watch":

a) first prize (author: "Naujoji architektūra ir grafika"); b) second prize (author: "Architektūros linija") 


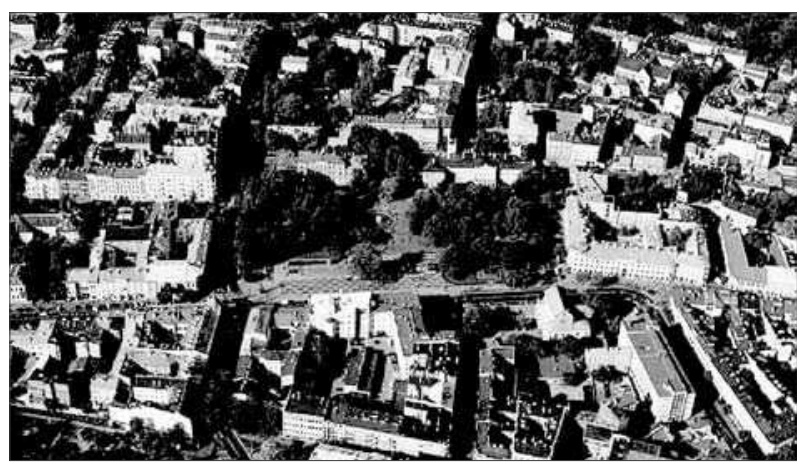

19 pav. Liublino (Lenkija) centrinès viešosios erdvès Skver Litewski dabartinis vaizdas

Fig. 19. Contemporary view of the public space Skver Litewski in Lublin (Poland)

patalpas, sumažinant miesto žaliuosius plotus, o kitas, priešingas pasiūlymas - minimaliai keisti susiklosčiusią situaciją, ją išryškinant ir pateikiant kaip neatsiejamą istorijos ir miesto dali (19, 20 pav.). Klasikinius viešosios erdvès sutvarkymo metodus pasirinko Estijos politikai, konkurse nugalètoju paskelbę tradicines vertybes ir laiko patikrintus simbolius deklaruojantị projektą (21 pav.).

Kadangi socialinis užsakymas posovietinėse valstybèse būna itin nebrandus ir nekonkretus, politikai bei miesto valdžia dažniausiai ieško įvairių alternatyvių nuomonių, tikisi netikètų naujų idèjų, stebi visuomenès reakciją. Tokiose neapibrěžtose situacijose itin aktyvi būna pelnu suinteresuotų verslininkų pozicija, nes nagrinejjamos teritorijos būna komerciškai patraukliausiose miestų erdvese. Nesuformulavus ir ịstatymiškai neapibrěžus kaip reikia atstovauti viešajam interesui, nenustačius aiškių finansavimo šaltinių, kūrybinès paieškos dažniausiai įstringa eskizų lygmenyje ir, nepasiekus konkrečių rezultatų, nukeliamos vèlesniam laikui.

Juridinių aspektų visuma, pagrịsta ịstatymų nebuvimu arba jų netobulumu, vengimas prisiimti bet kokio sprendimo atsakomybę, politinès valios nebuvimas, dominuojantis komercinis interesas dažniausiai sukuria visiško neveiklumo ir chaoso prielaidas. Tai ypač gerai iliustruoja Lietuvos pajūrio architektūros sprendimų bei planavimo realybè. Palangoje, vadovaujantis liberalaus verslo interesais, kyla, net sostinès masteliu vertinant, itin tankaus užstatymo pavyzdžiai, o Neringos unikalus gamtos draustinis niekaip negali pašalinti nuo sovietinių metų likusios urbanistinès taršos. Beatodairiškas saugojimas, esant nesutvarkytai juridinei bazei, realybejje sukūrẻ naują, ypatingą egzis-

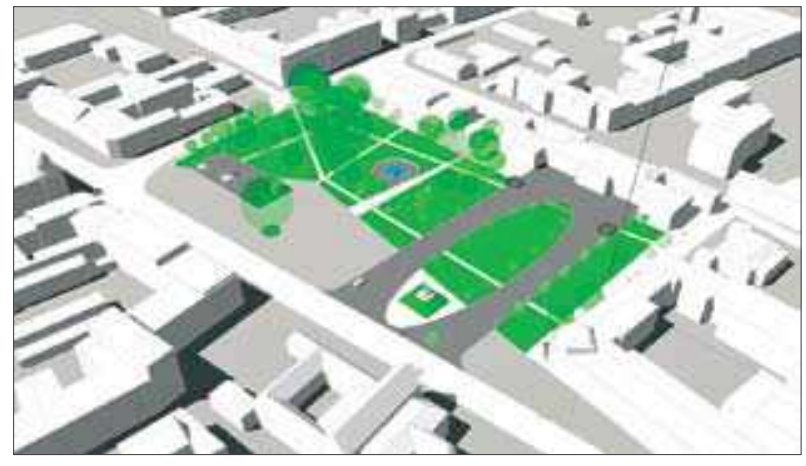

20 pav. Skvero sutvarkymo pasiūlymas (archit. G. Čaikauskas, S. Beyer)

Fig. 20. Proposal for reconstruction of the square (archs. G. Čaikauskas, S. Beyer)

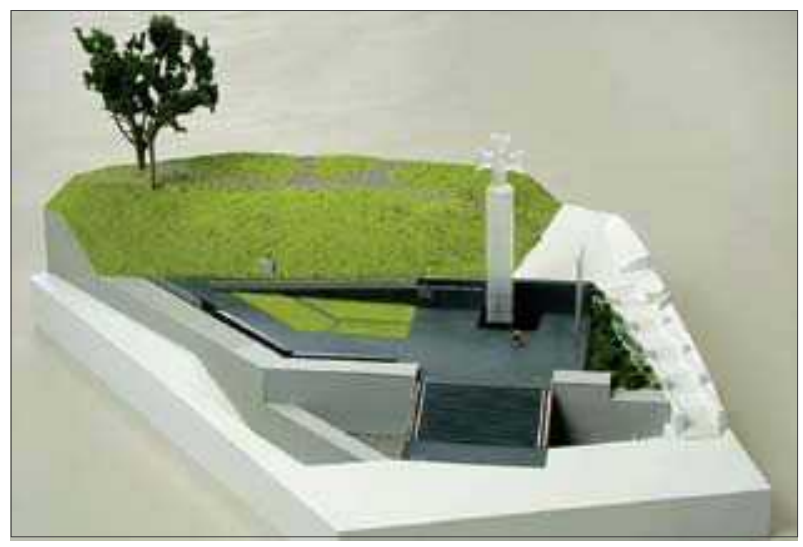

21 pav. Estijos nepriklausomybès kovų monumentas, sukurtas Talino centre esančioje viešojoje erdveje šalia natūraliai susiformavusio pèsčiųjų tako

Fig. 21. Monument of Estonian Independence in the centre of Tallinn by a footpath

tencinį fenomeną - ,juridinio nesvarumo būklę“. Šioje terpejje egzistuoja nesuvokiami, niekam nereikalingi, tačiau realiai apčiuopiami materijos likučiai, teikiantys ūkiškai mąstantiems savininkams būsimos investicijos prielaidas (22 pav., a, b, c, d). Gamtos aplinka lieka neišvalyta, „statinių vaiduoklių“ fragmentai negriaunami, todèl vietoje ekologinès švaros saugomoje, unikalioje teritorijoje ilgam laikui (tai trunka jau beveik dvidešimt metų) juridiškai užkonservuojama vizuali estetiné bei ekologinè aplinkos, t. y. viešosios erdvès, parko, prieinamo visiems, tarša. Galioja unikalus teisinis paradoksas - išsivysčiusiose šalyse nesuvokiamas žemètvarkinis sprendimas: neprivatizuojamoje Neringos teritorijoje suformuotos privačios valdos, valstybinis valdymas šiose vietose negalimas. Vyksta begaliniai 

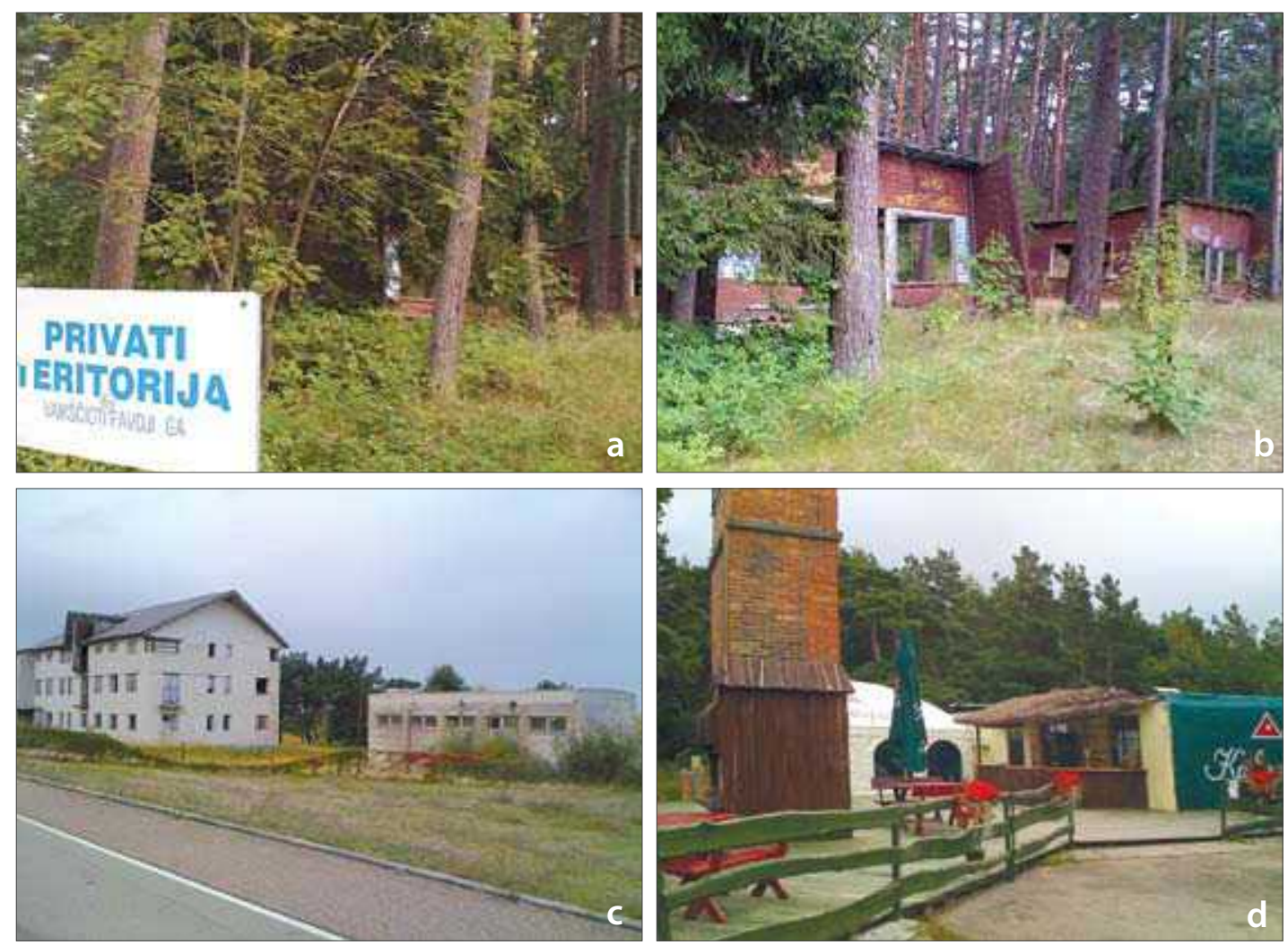

22 pav. Ekologinè ir vizualinė tarša Neringoje $(a, b, c, d)$

Fig. 22. Ecological and visual polution in Neringa (a, b, c, d)

teismai, rezultatai - neprognozuojami. Neveiklumas nèra ribojamas laiko, savininkas, per nustatytą terminą nesutvarkantis savo sklypo arba nepastatantis naujo objekto - nebaudžiamas. Jam suteikiama galimybė laukti geresnių politinių sprendimų ar palankesnès ekonominès situacijos.

\section{Išvados ir pasiūlymai}

1. Architektūra yra neatsiejama meninès kūrybos ir visuomenès civilizacijos dalis, todèl ją veikia visi charakteringi evoliucijos désniai. Iškylantys ịvairiausių prieštaravimų pradai siekia visuomeninès atskirties šaknis, tiesiogiai siejasi su visomis žmonijos gyvenime egzistuojančiomis problemomis. Jų galima išvengti arba bent sumažinti poveikị tik iš esmès sprendžiant visuomeninius prieštaravimus.

2. Kiekvienas prieštaravimų pradas yra neatskiriamas nuo konkrečios gyvenimo srities, yra pakankamai objektyvus. Tie pradai yra labai skirtingi, tačiau visi vienodai kenkia ir menkina galutinị subjektyvų kūrybos rezultatą.
3. Atskirties lygmuo yra atvirkščiai proporcingas šalių demokratijos tradicijoms, ekonomikos išsivystymui, gyventojų edukacijai, meninèms tradicijoms bei visuomeninei tolerancijai.

4. Aplinkos formavimą turi lemti ne vien pragmatiški politizuoti ekonomikos dèsniai, pagrịsti beribiu pelno siekimu, bet ir etikos bei moralès nuostatos.

5. Rengiant šalies politinès raidos kryptis bei programas, privalu akcentuoti ne nevaldomo liberalaus verslo plètros prioritetus, bet visuomeninès atskirties mažinimo tikslus. Kultūros, švietimo ir meninio pasirengimo aukštesnis lygis padés subalansuoti ekologinius bei ekonominius svertus, igyvendinti darnios plètros idejjas bei pasiekti bendrą civilizacijos progresą.

\section{Literatūra}

Vanagas, J. 2003. Miesto teorija. Vilnius: VDA leidykla. ISBN 9986-571-85-5.

Vanagas, J. 2008. Urbanistikos pagrindai. Vilnius: Technika. ISBN 978-9955-28-237-2.

Šepetys, L. 1982. Modernizmo metmenys. Vilnius: „Vagos“ leidykla. 
Visuotine lietuviu enciklopedija. 2001-2008. Vyr. redaktorius Antanas Račis. Vilnius: Mokslo ir enciklopedijų leidybos institutas. ISBN 5-420-01486-6.

Trilupaitytè, S.; Dubinskaite, R.; Tereškinas, A., ir kt. 2005. Pažymettos teritorijos. Vilnius: Tyto alba. ISBN 9986-16-410-9.

Bučys, A. 2008. Barbarai vice versa klasikai. Vilnius: Lietuvos rašytojų sąjungos leidykla.

Gedgaudas, Č. 1994. Mūsu praeities beieškant. Kaunas: „Aušros“ spaustuvè. ISBN 9986-407-11-7.

\section{DISJUNCTURE IN PUBLIC SPACE CONCEPTION}

\section{G. Čaikauskas}

Abstract. The paper is devoted to different aesthetic categories of the existing environment and to disjuncture between the social order, creators' ideas and public conception of the results. Architectural design presented as a dominating subject among artistic subjects reflects development of human culture as well as regular evolution of the whole civilization. Conflict sources reflect society's miscommunication reasons. Evaluation of artistic activities is based on outstanding examples of former and contemporary projects and realizations.

Keywords: disjuncture, environmental conception, conflict sources.

\section{GINTARAS ČAIKAUSKAS}

Architect, Professor (2006), Faculty of Architecture, Vilnius Gediminas Technical University (VGTU), Pylimo g. 26/Traku g. 1, LT-01132 Vilnius, Lithuania.

E-mail: gintaras.caikauskas@architekturoslinija.lt

Probation in Finland and USA (1990-1991). Membership: member of Lithuanian Union of Architects (1988); member (1999), chairman (2002) of Expert Council of Architecture and Urbanism in Lithuanian Union of Architects. Honorary awards: three awards for the best projects and realizations nominated by Lithuanian Union of Architects; two awards of Lithuanian Ministry of Environment nominated by Lithuanian Union of Architects; two golden medals for the best project realization of the year nominated by Lithuanian Confederation of Industrialists; award of Lithuanian Real Estate Association. Publications: author of 3 research papers and tens of publications in professional press. Projects: author of over 200 projects of architectural design. Research interests: theory and practice of architecture. 